\title{
Effects of Fly Ash Amendments, Ralstonia solanacearum, Meloidogyne incognita and Phomopsis vexans on the Growth of Solanum melongena
}

\author{
M. KHAN and Z. A. SIDDIQUI* \\ Department of Botany, Aligarh Muslim University, Aligarh-202002, India
}

(Received: 2 January 2017; accepted: 17 January 2017)

\begin{abstract}
Effects of fly ash amendments in soil (0\%, 25\% and 50\% vol/vol), Ralstonia solanacearum, Meloidogyne incognita and Phomopsis vexans were observed on the growth, chlorophyll and carotenoid contents of eggplant. Addition of $25 \%$ fly ash in soil caused a significant increase in plant growth, chlorophyll and carotenoid contents over plants grown without fly ash. However, amendments of 50\% fly ash in soil had an adverse effect on the growth, chlorophyll and carotenoid contents of eggplant. Inoculation of the pathogens caused a significant reduction in growth, chlorophyll and carotenoid contents. Inoculation of $R$. solanacearum caused the greatest reduction followed by $P$. vexans and $M$. incognita. Root galling and nematode multiplication was reduced with the increase in fly ash. Wilting and blight indices were 3 in plants grown in $0 \%$ and $25 \%$ fly ash amended soil while 4 in $50 \%$ fly ash amended soil.
\end{abstract}

Keywords: Egg plant, root knot nematode, wilt, blight.

Eggplant or brinjal (Solanum melongena L.) is an important solanaceous crop of sub-tropics and tropics. Eggplant has been cultivated in India for the last 4,000 years and produces about $7.676 \mathrm{M}$ t from an area of $0.472 \mathrm{M}$ ha with an average productivity of $16.3 \mathrm{mt} / \mathrm{ha}$ (www.ncpahindia.com/eggplant.php). Eggplant is known to suffer from many diseases and among them fruit and leaf blight caused by Phomopsis vexans (Sacc and Syd.) Harter, bacterial wilt caused by Ralstonia solanacearum (Smith) Yabuuchi et al. and root knot disease caused by Meloidogyne incognita (Kofoid and White) Chitwood are common. Root-knot nematodes are particularly damaging vegetables in tropical and subtropical countries of the world and cause losses up to $80 \%$ in heavily infested fields (Sikora and Fernandez, 2005). Ralstonia solanacearum is a Gram-negative, rod-shaped, strictly aerobic bacterium. $R$. solanacearum causes wilt and is one of the most important plant pathogenic bacterium responsible for great economic losses worldwide (Hayward, 1991). Similarly, Phomopsis vexans (teleomorph: Diaporthe vexans Gratz) is also a major constraint in the production of eggplant. Fruit rot and leaf blight disease caused by $P$. vexans is a major concern, reduces yield and marketable value of the crop nearly 20-30\% (Jain and Bhatnagar 1980; Kaur et al., 1985).

* Corresponding author; e-mail: zaki_63@yahoo.co.in 
In India alone, more than 112 million tons of fly ash is generated annually, and the production is projected to exceed 170 million tons per year (Sarkar et al., 2012). Burning of coal releases oxides of nitrogen and sulphur and enormous quantity of fly ash gets deposited on the soil and the plants. Fly ash is major solid waste as a coal combustion residue and recycling or safe disposal of solid industrial wastes has become a prime environmental concern throughout the world. Hence, many potential applications have been identified for the utilization of fly ash including soil amendments in agricultural fields.

Heavy metals (Fe, several micronutrients and toxic metals) are abundant in fly ash, with the deficiency of fixed C- and N-compounds (Martens et al., 1970; Parab et al., 2012). Several heavy metals are useful in minute quantities to plants and classified as micronutrients, which nonetheless are toxic at higher levels. Moreover, metal contents in fly ash are known to cause the enhancement of crop growth in amended soils. Fly ash has been used in amending soils supporting several crops (Korcak, 1995, Mishra et al., 2005, Mishra et al., 2007; Samy et al., 2010), as a method of sustainable waste disposal and soil fertilization, worldwide (Dick et al., 2000).

The present study was carried out to observe the effect of fly ash amendments on the growth, chlorophyll and carotenoid contents of eggplant both in the presence and absence of $R$. solanacearum, M. incognita and P. vexans.

\section{Materials and Methods}

Fly ash used in this experiment was collected from the thermal power plant (530 MW capacity) located at Kasimpur, Aligarh, India. This power plant consumes 3192 ton of bituminous coal per day and produces 650 ton per day of fly ash. The field soil (from Aligarh) used in the experiment was loam, containing 71\%, 18\% and $11 \%$ sand, silt and clay particles, respectively. Field soil as collected was autoclaved at $137.9 \mathrm{kPa}$ for 20 minutes while fly ash was dried in the sun for 10 days and mixed (vol:vol) in 3 proportions with soil, i.e. $0 \%$ (100\% soil), $25 \%$ and $50 \%$ fly ash. Clay pots (30 cm dia.) which were previously lined with polythene were filled with $3.5 \mathrm{~kg}$ of the ash-soil mixtures.

\section{Physico-chemical analyses}

The physico-chemical characters of the soils used in the treatments were determined before sowing the seeds of eggplant cultivar Navkiran (Table 1). The soil samples were passed through a $2 \mathrm{~mm}$ sieve before analyses and the following properties were determined: porosity and water holding capacity by hydrometry; $\mathrm{pH}$, conductivity and cation exchange capacity (CEC) using soil:distilled water in $\mathrm{pH}$ and conductivity meters. Organic carbon was estimated by Nelson and Sommers (1972). Sulphur, zinc, manganese, copper and iron by analytical methods (Chopra and Kanwar, 1982); nitrogen by Kjeldahl digestion (Nelson and Sommers, 1972); and phosphorus by phosphomolybdic blue colorimetry (Jackson, 1958). 
Table 1

Physico-chemical characteristics of soil mixed with fly ash

\begin{tabular}{lcccc}
\hline \multirow{2}{*}{ Characteristics } & \multicolumn{3}{c}{ Fly ash in field soil } & \multirow{2}{*}{ C.D. $P=0.05$} \\
\cline { 2 - 4 } $\mathrm{pH}$ & $5.9^{\mathrm{c}}$ & $25 \%$ & $50 \%$ & \\
\hline $\mathrm{CEC}(\mathrm{mmhos} / \mathrm{cm})$ & $0.997^{\mathrm{c}}$ & $6.7^{\mathrm{b}}$ & $7.5^{\mathrm{a}}$ & 0.4 \\
Water holding capacity $(\%)$ & $47.2^{\mathrm{c}}$ & $51.2^{\mathrm{b}}$ & $1.522^{\mathrm{b}}$ & 0.071 \\
Organic carbon $(\%)$ & $0.52^{\mathrm{a}}$ & $0.40^{\mathrm{b}}$ & $55.3^{\mathrm{a}}$ & 3.4 \\
$\mathrm{~N}(\mathrm{~kg} / \mathrm{ha})$ & $201.4^{\mathrm{a}}$ & $176.2^{\mathrm{b}}$ & $142.1^{\mathrm{c}}$ & 0.05 \\
$\mathrm{P}(\mathrm{kg} / \mathrm{ha})$ & $18.0^{\mathrm{a}}$ & $14.5^{\mathrm{b}}$ & $12.6^{\mathrm{c}}$ & 4.6 \\
$\mathrm{~K}(\mathrm{~kg} / \mathrm{ha})$ & $220.05^{\mathrm{c}}$ & $345.15^{\mathrm{b}}$ & $508.5^{\mathrm{a}}$ & 0.7 \\
$\mathrm{~S}\left(\mathrm{mg} \times \mathrm{kg}^{-1}\right)$ & $10.86^{\mathrm{c}}$ & $13.69^{\mathrm{b}}$ & $16.12^{\mathrm{a}}$ & 8.3 \\
$\mathrm{Zn}\left(\mathrm{mg} \times \mathrm{kg}^{-1}\right)$ & $5.82^{\mathrm{a}}$ & $3.64^{\mathrm{b}}$ & $2.94^{\mathrm{c}}$ & 0.6 \\
$\mathrm{Fe}\left(\mathrm{mg} \times \mathrm{kg}^{-1}\right)$ & $4.80^{\mathrm{a}}$ & $4.27^{\mathrm{b}}$ & $4.06^{\mathrm{c}}$ & 0.24 \\
$\mathrm{Mn}\left(\mathrm{mg} \times \mathrm{kg}^{-1}\right)$ & $2.71^{\mathrm{c}}$ & $2.86^{\mathrm{b}}$ & $3.04^{\mathrm{a}}$ & 0.14 \\
$\mathrm{Cu}\left(\mathrm{mg} \times \mathrm{kg}^{-1}\right)$ & $0.42^{\mathrm{c}}$ & $0.55^{\mathrm{b}}$ & $0.63^{\mathrm{a}}$ & 0.08 \\
\hline
\end{tabular}

*Values in a row followed by the different letters are significantly different at $P \leq 0.05$ using Duncan's multiple range test. Multiplication factors for converting $\mathrm{mg}$ of mineral per $\mathrm{kg}$ of soil to kilograms per hectare $(\mathrm{kg} / \mathrm{ha})$ were calculated for a $30-\mathrm{cm}$ soil layer

*C.D. $=$ Critical difference

\section{Plant culture}

Five seeds of eggplant cultivar Navkiran were sown separately in the three soilfly ash mixtures after surface sterilization by $0.1 \%$ sodium hypochlorite. Two weeks after germination thinning was done and a healthy seedling was maintained in each pot. Plants grown in each type of soil were inoculated with $R$. solanacearum, $M$. incognita, $P$. vexans and control (without pathogen). Each treatment was replicated five times $(12 \times 5=60$ pots $)$. The pots were arranged on a glasshouse bench at $30{ }^{\circ} \mathrm{C}$ and watered regularly. The experiment was terminated 120 days after inoculation.

\section{Fungus inoculum}

Phomopsis vexans was isolated from infected eggplant leaf having blight symptoms. $P$. vexans was characterized as it produces only one type of conidia in its pycnidia, which are hyaline, one celled, sub-cylindrical and 5-9 $\times 2-2.8 \mu$ in size during summer months, which gradually changed into the beta form (Islam et al., 2010). Inoculation of host plants with beta conidia caused intraveinal necrosis, which progressed towards the leaf base and resulted in premature defoliation, thus indicating their role in pathogenesis. Fungus was grown in Petri dishes containing potato dextrose agar (PDA) medium at 
$25^{\circ} \mathrm{C}$ for 15 days. For obtaining sufficient inoculum, $P$. vexans was cultured on Richard's liquid medium (Riker and Riker, 1936) having the following composition:

$\begin{array}{lr}\text { Potassium nitrate } & 10.00 \mathrm{~g} \\ \text { Potassium dihydrogen phosphate } & 5.00 \mathrm{~g} \\ \text { Magnesium sulphate } & 2.50 \mathrm{~g} \\ \text { Ferric chloride } & 0.02 \mathrm{~g} \\ \text { Sucrose } & 50.00 \mathrm{~g} \\ \text { Distilled water } & 1000 \mathrm{ml}\end{array}$

The medium was prepared and filtered through muslin cloth, sterilized in an autoclave at $103.4 \mathrm{kPa}$ for 15 minutes in $250 \mathrm{ml}$ Erlenmeyer flasks each containing $80 \mathrm{ml}$ liquid medium. The fungus was inoculated in each flask with the help of an inoculation needle. Inoculated flasks were incubated at $25 \pm 1{ }^{\circ} \mathrm{C}$ for about 15 days. After sufficient growth of the fungus, liquid medium was filtered through Whatman filter paper No. 1. The mat of fungal mycelium was washed in distilled water and any excess of water and nutrients were removed with the help of blotting paper. The inoculum was prepared by mixing $10 \mathrm{~g}$ fungal mycelium in $100 \mathrm{ml}$ of distilled water and blending for 30 seconds in a Waring blender. Twenty $\mathrm{ml}$ of this suspension, containing $2 \mathrm{~g}$ fungus, was inoculated.

\section{Bacterial inoculum}

Eggplants showing typical symptoms of bacterial wilt were collected from eggplant fields. Stems of infected eggplants were cut obliquely at the base and placed in sterile distilled water. The stem pieces showing milky white ooze in water were selected for isolation of the pathogen. The pathogen was isolated on nutrient agar medium. Nutrient agar plates were streaked separately with a pure colony of $R$. solanacearum and incubated at $30{ }^{\circ} \mathrm{C}$ for $24 \mathrm{~h}$. Single colonies from a 24-h-old pure culture of either $R$. solanacearum were inoculated separately into nutrient broth liquid medium (peptone $5 \mathrm{~g} / \mathrm{L}$; meat extract $1 \mathrm{~g} / \mathrm{L}$; yeast extract $2 \mathrm{~g} / \mathrm{L}$; sodium chloride $5 \mathrm{~g} / \mathrm{L} ; \mathrm{pH}$ 7.0) in flasks and incubated at $30{ }^{\circ} \mathrm{C}$ for $72 \mathrm{~h}$. Bacterial cell density in the concentrated suspension was determined following Sharma (2001) and $1.2 \times 10^{5}$ colony-forming units (c.f.u.)/ml was adjusted by adding required amount of sterilized water calculated mathematically. Twenty ml bacterial suspension was inoculated per pot.

\section{Nematode inoculum}

Meloidogyne incognita was collected from the eggplant roots and multiplied on the roots of egg plants using single egg mass. Large numbers of egg masses from heavily infected eggplant roots were hand-picked with the help of sterilized forceps. The egg masses were washed with distilled water and placed in a small sieve $(9 \mathrm{~cm}$ diameter with 1-mm pore size) containing crossed layers of tissue paper. The sieve was placed in a Petri dish containing distilled water deep enough to contact the egg masses. A number of these assemblies were kept in an incubator running at $25 \pm 1{ }^{\circ} \mathrm{C}$ in order to obtain the required 
number of second-stage juveniles for inoculation. The hatched second-stage juveniles were collected from the Petri dishes every $24 \mathrm{~h}$, fresh water was added, and the process was repeated. For counting nematode juveniles, an average of 5 counts was made to determine the density of nematodes in the suspension. The volume of nematode suspension was so adjusted that each $\mathrm{ml}$ may contain $200 \pm 5$ nematodes. Twenty $\mathrm{ml}$ of this suspension (i.e. 4000 freshly hatched juveniles) was added to each pot around a eggplant seedling.

\section{Experimental design}

Soil around the roots was carefully removed and suspensions of $M$. incognita, $R$. solanacearum and $P$. vexans were poured around the roots uniformly and soil replaced. In control pots, water was poured in similar amount to inoculum suspension. Three types of soil were used, viz. 0:100 (\% v/v) fly ash:soil; 25:75 fly ash:soil; 50:50 fly ash:soil, respectively. These soil mixtures were inoculated with $M$. incognita, $R$. solanacearum and $P$. vexans alone and a control (Table 2). There were 12 treatments, i.e. 3 types of soil

\section{Table 2}

Effects of fly ash, Ralstonia solanacearum, Meloidogyne incognita and Phomopsis vexans on the growth of eggplant

\begin{tabular}{|c|c|c|c|c|c|c|}
\hline Treatment & & $\begin{array}{l}\text { Plant } \\
\text { length } \\
(\mathrm{cm})\end{array}$ & $\begin{array}{l}\text { Plant fresh } \\
\text { weight } \\
(\mathrm{g})\end{array}$ & $\begin{array}{c}\% \text { increase }(+) \text { or } \\
\text { decrease }(-) \text { in shoot dry } \\
\text { weight over control }\end{array}$ & $\begin{array}{l}\text { Shoot dry } \\
\text { weight } \\
(\mathrm{g})\end{array}$ & $\begin{array}{l}\text { Root dry } \\
\text { weight } \\
(\mathrm{g})\end{array}$ \\
\hline \multirow[t]{3}{*}{ Control } & $0 \%$ Fly ash & $76.8^{\mathrm{b}}$ & $62.32^{\mathrm{b}}$ & - & $13.58^{b}$ & $2.34^{\mathrm{b}}$ \\
\hline & $25 \%$ Fly ash & $82.7^{\mathrm{a}}$ & $65.61^{\mathrm{a}}$ & +10.16 & $14.96^{\mathrm{a}}$ & $2.81^{\mathrm{a}}$ \\
\hline & $50 \%$ Fly ash & $72.4^{\mathrm{c}}$ & $60.43^{c}$ & -10.08 & $12.21^{\mathrm{c}}$ & $1.93^{\mathrm{c}}$ \\
\hline \multirow[t]{3}{*}{ R. solanacearum } & $0 \%$ Fly ash & $55.4^{\mathrm{hi}}$ & $31.63^{\mathrm{i}}$ & - & $8.16^{\mathrm{h}}$ & $1.13^{\mathrm{fg}}$ \\
\hline & $25 \%$ Fly ash & $57.9^{\mathrm{g}}$ & $33.62^{\mathrm{h}}$ & +5.26 & $8.59^{\mathrm{g}}$ & $1.40^{\mathrm{ef}}$ \\
\hline & $50 \%$ Fly ash & $54.2^{\mathrm{i}}$ & $29.61^{j}$ & -9.06 & $7.42^{\mathrm{i}}$ & $1.00^{\mathrm{g}}$ \\
\hline \multirow[t]{3}{*}{ M. incognita } & $0 \%$ Fly ash & $63.7^{\mathrm{e}}$ & $42.72^{\mathrm{d}}$ & - & $9.80^{\mathrm{e}}$ & $1.57^{\mathrm{de}}$ \\
\hline & $25 \%$ Fly ash & $66.8^{d}$ & $44.23^{\mathrm{d}}$ & +12.44 & $11.02^{\mathrm{d}}$ & $1.77^{\mathrm{cd}}$ \\
\hline & $50 \%$ Fly ash & $60.7^{\mathrm{f}}$ & $39.92^{\mathrm{e}}$ & -0.81 & $9.72^{\mathrm{e}}$ & $1.47^{\mathrm{e}}$ \\
\hline \multirow[t]{3}{*}{ P. vexans } & $0 \%$ Fly ash & $58.2^{\mathrm{g}}$ & $35.82^{\mathrm{g}}$ & - & $9.08^{f}$ & $1.32^{\mathrm{ef}}$ \\
\hline & $25 \%$ Fly ash & $61.2^{\mathrm{f}}$ & $37.92^{f}$ & +6.93 & $9.71^{\mathrm{e}}$ & $1.51^{\mathrm{de}}$ \\
\hline & $50 \%$ Fly ash & $56.8^{\mathrm{gh}}$ & $33.22^{\text {hi }}$ & -9.58 & $8.21^{\mathrm{gh}}$ & $1.28^{\mathrm{efg}}$ \\
\hline \multirow[t]{3}{*}{ C.D. at $5 \%$} & Pathogen (P) & 1.092 & 0.806 & - & 0.238 & 0.152 \\
\hline & Soil type (S) & 0.945 & 0.931 & - & 0.206 & 0.132 \\
\hline & Interactions $(\mathrm{P} \times \mathrm{S})$ & 1.897 & 1.612 & - & $0.412 *$ & $0.264^{*}$ \\
\hline
\end{tabular}

Values in a column followed by the different letters are significantly different at $P \leq 0.05$ using Duncan's multiple range test

C.D. $=$ Critical difference 
mixtures $\times 4$ treatments including control. Each treatment was replicated five times, i.e. $12 \times 5=60$ pots and the experiment was conducted in bi-factorial design.

\section{Evaluation of experiment}

The plants were harvested 120 days after inoculation. Data on plant length, fresh plant weight, plant dry weight, number of galls, nematode population, chlorophyll and carotenoid contents were recorded. Wilt and blight indices and number of galls, nematode population were also recorded. The length of plants was recorded in $\mathrm{cm}$ from the top of the first leaf to end of the root. Excess water was removed by blotting before weighing the plant for fresh weight. The plants were cut with a knife above the base of the root emergence zone to separate shoot and root. Shoots and roots were kept in envelopes at $60{ }^{\circ} \mathrm{C}$ for 2-3 days before weighing for dry weight. A $250 \mathrm{~g}$ subsample of well-mixed soil from each treatment was processed by Cobb's sieving and decanting technique followed by Baermann funnel extraction (Southey, 1986). Nematode suspension was collected after 24 $\mathrm{h}$ and the numbers of nematodes were counted in five aliquots of $1 \mathrm{ml}$ of suspension from each sample. The means of five counts were used to calculate the population of nematodes in $3.5 \mathrm{~kg}$ soil. To estimate the number of juveniles, eggs and females inside the roots, a $1 \mathrm{~g}$ subsample of roots was macerated in a Waring blender and counts were made from the suspension thus obtained. Numbers of nematodes present in roots were calculated by multiplying the number of nematodes present in $1 \mathrm{~g}$ of root by the total weight of root. Wilt and blight indices were determined by scoring the severity of disease on a scale ranging from 0 to 5 where $0=$ no disease (no wilt/blight symptoms observed); $1=$ wilt/blight symptoms up to $12.5 \%$ on shoot; 2 = wilt/blight symptoms 12.6 to $25 \%$ on shoot; $3=$ wilt/ blight symptoms 25.1 to $37.5 \%$ on shoot; 4 = wilt/blight symptoms 37.6 to $50 \%$ on shoot, and $5=$ more than $50 \%$ wilt/blight symptoms on shoot. The chlorophyll and carotenoid contents in fresh leaves were estimated following the method of Mackinney (1941).

\section{Statistical analysis}

Data obtained were analysed statistically http://hau.ernet.in/about/opstat.php (for off campus users) using two factorial analysis of variance (ANOVA) (i.e. pathogens $\times$ types of soil). Effects of types of soil and pathogens and their interaction were calculated. Critical differences (C.D.) were calculated at $P=0.05$, Duncan's multiple range test was later employed to denote significant differences between the treatments.

\section{Results}

\section{Physico-chemical characteristics}

Addition of fly ash resulted in the increase of soil $\mathrm{pH}, \mathrm{CEC}$, water holding capacity, potassium, sulphur, manganese and copper (Table 1). Amendment of 50\% fly ash caused 
greater increase in $\mathrm{pH}, \mathrm{CEC}$, water holding capacity, potassium, sulphur, manganese and copper than the addition of $25 \%$ fly ash. However, organic carbon, nitrogen, phosphorus, zinc and iron were reduced with the addition of fly ash. Amendment of $50 \%$ fly ash caused greater reduction than caused by $25 \%$ fly ash (Table 1 ).

\section{Plant growth}

Plants grown in $25 \%$ fly ash amended soil showed a significant increase in shoot dry weight as compared to plants grown in soil without fly ash (Table 2). However, addition of $50 \%$ fly ash to the soil caused a reduction in shoot dry weight. Inoculation of $M$. incognita/R. solanacearum or $P$. vexans caused a significant reduction in shoot dry weight in all types of soil mixtures compared to their respective control. Inoculation of $R$. solanacearum caused the greatest reduction in shoot dry weight followed by $P$. vexans and $M$. incognita. Addition of $25 \%$ fly ash to the soil caused $10.16 \%$ increase in shoot dry weight over plants grown without fly ash amended soil. However, application of $50 \%$ fly ash in the soil resulted in $10.08 \%$ reduction in shoot dry weight compared to plants grown in soil without fly ash. After inoculation with $R$. solanacearum, shoot dry weight was $5.26 \%$ higher in plants grown in $25 \%$ fly ash amended soil compared to plants grown without fly ash amendments. However, inoculation of $R$. solanacearum to plants grown in $50 \%$ fly ash amended soil resulted in $9.06 \%$ reduction in shoot dry weight compared to plants inoculated with $R$. solanacearum and grown without fly ash amendment. Increase in shoot dry weight was $12.44 \%$ in plants inoculated with $M$. incognita and grown with $25 \%$ fly ash amended soil compared to plants inoculated with $M$. incognita and grown without fly ash amendments. However, reduction in plant growth was $0.81 \%$ in plants inoculated with $M$. incognita and grown in 50\% fly ash amended soil compared to plants inoculated with $M$. incognita and grown without fly ash. Increase in shoot dry weight was $6.93 \%$ in plants inoculated with $P$. vexans and grown with $25 \%$ fly ash amendment compared to plants inoculated with $P$. vexans and grown without fly ash amendments. However, reduction in shoot dry weight was $9.58 \%$ in plants inoculated with $P$. vexans when grown in 50\% fly ash amended soil compared to plants inoculated with $P$. vexans and grown without fly ash (Table 2).

Plant length, fresh weight and root dry weight were also increased with the addition of $25 \%$ fly ash to the soil (Table 2). However, addition of $50 \%$ fly ash to the soil had adverse effect on plant length, fresh weight and root dry weight. Inoculation of $M$. incognita/R. solanacearum or $P$. vexans caused a significant reduction in plant length, fresh weight and root dry weight in all types of soil mixtures compared to their respective control. Inoculation of $R$. solanacearum caused the greatest reduction in plant length, fresh weight and root dry weight followed by $P$. vexans and $M$. incognita ( Table 2).

\section{Chlorophyll and carotenoid contents}

Plants grown in 25:75 fly ash:soil mixture showed a significant increase in chlorophyll and carotenoid contents compared to plants grown in the field soil (Table 3). However, $50 \%$ amendment with fly ash resulted in the reduction of chlorophyll and carote- 
noid contents compared to the plants grown in the soil without fly ash. Inoculation of $M$. incognita/R. solanacearum or $P$. vexans caused a significant reduction in chlorophyll and carotenoid contents as compared to their respective control. The results indicate that $R$. solanacearum caused the greatest reduction in chlorophyll and carotenoid contents followed by $P$. vexans and M. incognita in all fly ash and soil mixtures. (Table 3).

\section{Root galling and nematode multiplication}

Root galling and nematode multiplication was greater in plants grown in the soil without fly ash ash compared to plants grown in fly ash amended soil (Table 3). We found that galling and nematode population decreased with increasing fly ash content of the soil. The least galling intensity and nematode multiplication was observed in plants grown in $50 \%$ fly ash amended soil.

\section{Table 3}

Effects of fly ash, Ralstonia solanacearum, Meloidogyne incognita and Phomopsis vexans on chlorophyll and carotenoid contents of eggplant

\begin{tabular}{|c|c|c|c|c|c|c|}
\hline Treatment & & $\begin{array}{c}\text { Chlorophyll } \\
(\mathrm{mg} / \mathrm{g})\end{array}$ & $\begin{array}{c}\text { Carotenoid } \\
(\mathrm{mg} / \mathrm{g})\end{array}$ & $\begin{array}{c}\text { Number of } \\
\text { galls/root }\end{array}$ & $\begin{array}{l}\text { Nematode } \\
\text { population }\end{array}$ & $\begin{array}{l}\text { Wilt / blight } \\
\text { index }\end{array}$ \\
\hline \multirow[t]{3}{*}{ Control } & $0 \%$ Fly ash & $1.848^{\mathrm{b}}$ & $0.052^{\mathrm{b}}$ & - & - & - \\
\hline & $25 \%$ Fly ash & $2.035^{\mathrm{a}}$ & $0.058^{\mathrm{a}}$ & - & - & - \\
\hline & $50 \%$ Fly ash & $1.717^{\mathrm{c}}$ & $0.046^{\mathrm{cd}}$ & - & - & - \\
\hline \multirow[t]{3}{*}{ R. solanacearum } & $0 \%$ Fly ash & $0.970^{\mathrm{h}}$ & $0.045^{\mathrm{d}}$ & - & - & 3 \\
\hline & $25 \%$ Fly ash & $1.135^{\mathrm{g}}$ & $0.048^{\mathrm{c}}$ & - & - & 3 \\
\hline & $50 \%$ Fly ash & $0.901^{\mathrm{i}}$ & $0.039^{\mathrm{e}}$ & - & - & 4 \\
\hline \multirow[t]{3}{*}{ M. incognita } & $0 \%$ Fly ash & $1.477^{\mathrm{d}}$ & $0.050^{\mathrm{bc}}$ & $228^{\mathrm{a}}$ & $45400^{\mathrm{a}}$ & - \\
\hline & $25 \%$ Fly ash & $1.850^{\mathrm{b}}$ & $0.052^{\mathrm{b}}$ & $164^{\mathrm{b}}$ & $32980^{\mathrm{b}}$ & - \\
\hline & $50 \%$ Fly ash & $1.397^{\mathrm{e}}$ & $0.039^{\mathrm{e}}$ & $104 \mathrm{c}$ & $19700^{c}$ & - \\
\hline \multirow[t]{3}{*}{ P. vexans } & $0 \%$ Fly ash & $1.390^{\mathrm{e}}$ & $0.050^{\mathrm{b}}$ & - & - & 3 \\
\hline & $25 \%$ Fly ash & $1.458^{\mathrm{d}}$ & $0.051^{\mathrm{b}}$ & - & - & 3 \\
\hline & $50 \%$ Fly ash & $1.269^{\mathrm{f}}$ & $0.045^{\mathrm{d}}$ & - & - & 4 \\
\hline \multirow[t]{3}{*}{ C.D. at $5 \%$} & Pathogen (P) & 0.029 & 0.001 & - & - & - \\
\hline & Soil type (S) & 0.025 & 0.001 & - & - & - \\
\hline & Interactions $(\mathrm{P} \times \mathrm{S})$ & 0.051 & 0.002 & 16.2 & 1174.2 & - \\
\hline
\end{tabular}

Values in a column followed by the different letters are significantly different at $P \leq 0.05$ using Duncan's multiple range test

C.D. $=$ Critical difference 


\section{Disease indices}

Wilt and blight indices were 3 when $R$. solanacearum and $P$. vexans inoculated plants were grown in soil without fly ash and also in $25 \%$ fly ash amended soil (Table 3 ). The disease indices were 4 when $R$. solanacearum and $P$. vexans were inoculated into $50 \%$ fly ash amended soil.

\section{Discussion}

The improved growth, chlorophyll and carotenoid contents of eggplant in $25 \%$ fly ash amended soil was apparently due to the availability of a greater amount of utilizable plant nutrients as revealed by the chemical analysis of the soil. A greater amount of potassium, sulphur, manganese and copper etc. present in the fly ash amended soil have been absorbed by the roots and utilized by the plant that led to improved growth of egg plant. The nutrients from fly ash have been reported to be beneficial for the plant growth and yield of rice (Sarangi et al., 1997), wheat, chickpea (Dubey et al., 1982) and tomato (Khan and Khan, 1996). However, plants grown in 50\% fly ash amended soil showed a decrease in plant growth, chlorophyll and carotenoid contents, probably due to excess of plant nutrients or to a build-up of certain toxic elements (Wadge and Hutton, 1987) at a level that became phytotoxic and inhibited plant growth.

After inoculation with $R$. solanacearum and $P$. vexans or $M$. incognita, a considerable increase in plant growth, chlorophyll and carotenoid contents were observed in plants grown in $25 \%$ fly ash amended soil compared to plants grown in the soil without fly ash. Greater availability of nutrients in fly ash-amended soil enabled the plants to grow better and may inhibit invasion of $M$. incognita. Higher uptake of boron and potassium etc. helped the plants in building natural defences against the nematode (Kirkpatrick et al., 1964; Francois, 1984; Khan et al., 1997). Therefore, galling and nematode multiplication was reduced with the addition of fly ash. Moreover, excess of salts, i.e. chlorides, carbonates, bicarbonates, sulphates etc. (Khan and Khan, 1996), nutrients (Elseewi et al., 1981), heavy metals (Wadge and Hutton, 1987) and/or poly-chlorinated compounds (Helder et al., 1982; Sawyer et al., 1983) with the amendment of 50\% fly ash caused toxic effect on $M$. incognita either in soil or within the host. The substantial decline in the galling and nematode population indicates that the fly ash caused direct inhibitory effect on the survival and multiplication of $M$. incognita.

Amendment of $25 \%$ fly ash had no apparent effect on the blight and wilt disease indices of eggplant. Moreover, there was no substantial decline in the soil population of the $P$. vexans or $R$. solanacearum (data not shown) with the addition of fly ash indicates that the fly ash caused no direct inhibitory effect on the survival and multiplication of the fungal/bacterial pathogens in the soil. However, amendment of 50\% fly ash caused an increase in blight and wilt disease indices without increase in the soil population of the $P$. vexans or $R$. solanacearum. Plants grown in $50 \%$ fly ash amended soil were poor in growth as compared to plants grown in $25 \%$ fly ash amended soil and plants grown in the soil without fly ash. Plants grown in $50 \%$ fly ash amended soil had more severe disease 
symptoms than those grown in $25 \%$ fly ash amended soil because plants grown in $50 \%$ fly ash amended soil with severe disease symptoms were poor in growth. It is a general observation that more vigorous plants suffer less damage from pathogens as compared to plants restricted in growth (Agrios, 2005) which is also indicated by increased wilt and blight indices.

\section{Acknowledgement}

First author is thankful to U.G.C. New Delhi for the award of Junior Research fellowship to carry out this work.

\section{Literature}

Agrios, G. N. (2005): Plant Pathology (Fifth ed.). Elsevier Academic Press, London, UK. pp. 1-922.

Chopra, S. L. and Kanwar, J. S. (1982): Analytical Agricultural Chemistry. Kalyani publishers, New Delhi, $162 \mathrm{p}$.

Dick, W. A., Hao, Y. L., Stehouwer, R. C., Bigham, J. M., Wolfe, W. E., Adriano, D., Beeghly, J. H. and Haefner, R. J. (2000): Beneficial uses flue gas desulphurization by-products: Examples and case studies of land application. In: J. M. Bartels and W. A. Dick (eds): Land Application of Agricultural, Industrial and Municipal by-products. Soil Science Society of America, Madison, USA: American Society of Agronomy, pp. 505-536.

Dubey, P. S., Pawar, K. and Trivedi, L. (1982): Effect of fly ash deposition on photosynthetic pigment and dry matter production of wheat and gram. Agro-Ecosystem 8, 137-140.

Elseewi, A. A., Grimm, S. R., Page, A. L. and Straughan, I. R. (1981): Boron enrichment of plants and soil treated with coal ash. J. Plant Nutri. 3, 409-427.

Francois, L. E. (1984): Effect of excess boron on tomato yield, fruit size and vegetable growth. J. Amer. Soc. Hort. Sci., 109, 322-324.

Hayward, A. C. (1991): Biology and epidemiology of bacterial wilt caused by Pseudomonas solanacearum. Annu. Rev. Phytopathol. 29, 65-87.

Helder, T., Stutterheim, E. and Olie, K. (1982): The toxicity and toxic potential of fly ash from municipal incinerators assessed by means of a fish early life stage test. Chemosphere 11, 965-972.

Islam, M. M., Asaduzzaman, M., Hoque, M. E. and Meah, M. B. (2010): Morphological characterization of isolates of Phomopsis vexans in Bangladesh. J. Sci. Foundation 8, 123-130.

Jackson, M. L. (1958): Soil Chemical Analysis. Prentice Hall, Inc., Englewood Cliffs, NJ., 521 p.

Jain, M. R. and Bhatnagar, M. K. (1980): Efficacy of certain chemicals in the control of fruit rot of brinjal. Pesticides 14, 27-28.

Kaur, S., Kaur, R., Kaur, P. and Singh, D. (1985): Studies on wilt and fruit rot of brinjal caused by Fusarium semitectum. Indian Phytopathol. 38, 736-738.

Khan, M. R. and Khan, M. W. (1996): Effect of fly ash on plant growth and yield of tomato. Environ. Pollu., 92, 105-112.

Khan, M. R., Khan, M. W. and Singh, K. (1997): Management of root-knot disease of tomato by the application of fly ash in soil. Plant Pathology 46, 33-43.

Kirkpatrick, J. D., Mai, W. F., Parker, K. G. and Fisher, E. G. (1964): Effect of phosphorus and potassium nutrition of sour cherry on the soil population levels of five plant parasitic nematodes. Phytopathology 54, $706-712$.

Korcak, R. F. (1995): Utilization of coal combustion by-product in agriculture and horticulture. In: D. L. Karlen, R. J. Wright and W. D. Kemper (eds): Agricultural Utilization of Urban and Industrial by-products. Madison, USA: ASA Special Publication: pp. 107-130. 
Mackinney, G. (1941): Absorption of light by chlorophyll solutions. J. Biol. Chem. 140, 315-322.

Martens, D. C., Schnappinger, M. G. and Zelazny, L. W. (1970): The plant availability of potassium in fly ash. Proc. Soil Sci. Soc. Am. 34, 453-456.

Mishra, M., Sahu, R. K. and Padhy, R. N. (2005): Growth, yield, metabolism and elemental status of green gram (Phaseolus aureus) and til (Sesamum indicum) grown in soils amended with fly ash. Fresen Environ Bull, $14,559-564$.

Mishra, M., Sahu, R. K. and Padhy, R. N. (2007): Growth, yield, metabolism and elemental status of rice (Oryza sativa L.) grown in fly ash amended soils. Ecotoxicol. 16, 271-278.

Nelson, D. W. and Sommers, L. F. (1972): A simple digestion procedure for estimation of total nitrogen in soil and sediments. J. Environ. Qual. 1, 423-425.

Parab, N., Mishra, S. and Bhonde, S. R. (2012): Prospects of bulk utilization of fly ash in agriculture for integrated nutrient management. Bull. Nat. Inst. Ecol. 23, 31-46.

Riker, A. J. and Riker, R. S. (1936): Introduction to Research on Plant Diseases. John Swift Co., St. Louis, Chicago, $117 \mathrm{p}$.

Samy, N. T., Mishra, M., Sahu, R. K. and Padhy, R. N. (2010): Growth, yield and metabolism of rice (Oryza sativa $\mathrm{L}$.) during repeated applications of fly ash on soil. Advan. Food Sci, 32, 110-117.

Sarangi, P. K., Mishra, T. K. and Mishra, P. C. (1997): Soil metabolism, growth and yield of Oryza sativa L. in fly ash amended soil. Indian J. Environ. Sci. 1, 17-24.

Sarkar, A., Singh, A. and Agarawal, S. B. (2012): Utilization of fly ash as soil amendments in agricultural fields on North-Eastern gangetic plains of India: potential benefits and risks assessments. Bull. Nat. Inst. Ecol. 23, 9-20.

Sawyer, T., Bandiera, S., Safe, S., Olie, K. and Hutzinger, O. (1983): Bioanalysis of poly chlorinated dibenzufuran and dibenzo-p-dioxin mixture in fly ash. Chemosphere 12, 526-536.

Sharma, P. D. (2001): Microbiology. Rastogi and Company, Meerut, India, 359 p.

Sikora, R. A. and Fernandez, E. (2005): Nematode parasites of vegetables. In: M. Luc, R. A. Sikora and J. Bridge (eds): Plant Parasitic Nematodes in Subtropical and Tropical Agriculture. 2nd ed., CABI publishing, pp. 319-392.

Southey, J. F. (1986): Laboratory Methods for Work with Plant and Soil Nematodes. Her Majesty's Stationery Office, London, UK., ISBN-13: 978-0112427544, 202 p.

Wadge, A. and Hutton, M. (1987): The leachability and chemical speciation of selected trace elements in fly ash from coal combustion and refuse incinerators. Environ. Pollu. 48, 85-99. 
